\title{
The Relationship between Health and Ethical Conduct in Philosophical Perspective of Ayurveda (An Ancient Indian Medical Science)
}

\author{
By Rajyashree Yadav *
}

Ayurveda is an ancient Indian medical science. It flourished in India around 1000 B.C. and still provides effective treatment and preventive measures related with health \& fitness. In Ayurveda, the theory of health and disease is built on the metaphysical assumptions of two famous philosophical systems named Samkhya and Vaisheshika to explain the nature and basic constituents of the human body. Ayurveda describes the natural uniformity of all creations whether living or non-living. There is always a continuous reaction between human body and external environment. Both are assumed to consist of same elements identified as Panch Mahabhutas in Ayurveda. Since the human body has the same elements as nature, we must follow a life style which is in unison with nature. With the changes in nature and environment during different seasons and also during day and night, our regimen and other daily activities should also change. What we eat during daytime can be different from what we eat during night to remain healthy. The same concept applies to different weathers and seasons. When the balance between nature and human body disturbs, we get ailments. Apart from describing the relationship between body and environment, Ayurveda also imposes the responsibility upon human beings of maintaining nature in its best condition. The ideal life style for mankind shall preserve nature and should not destroy its natural contents. If human activities destroy or distort the natural environment they are considered unethical in Ayurveda. Such unethical behavior is the cause of various diseases and sufferings. It not only harms nature but is also fatal for the human body. By analyzing the concepts of mankind and its health \& disease, we can trace out the structure of ideal and meaningful lifestyle for human race that will ensure nature's protection and a healthy mind and body for every human being. In this paper an attempt is made to put forward the ideal way of life and human conduct according to the Ayurveda and to prescribe methods on which various human activities can be judged as ethical or non-ethical and beneficial or harmful for nature and human race.

*Lecturer, Govt. R.D. Girls College, Bharatpur, Rajasthan, India. 


\section{Introduction}

Ayurveda is an ancient Indian medical science which flourished and developed in Indian sub continent. Scholars have traced the origins of Ayurveda back to $5000 \mathrm{BCE}$ originating as an oral tradition (Gorakhnath \& Kashinath, 2008). Later, as medical texts, Ayurveda evolved from the Vedas and gained prominence as a medical science during $100 \mathrm{BCE}$ to $100 \mathrm{CE}$.

It has a long and rich tradition of serving people with its diagnosis and medicines. Among the four Vedas the Atharvaveda is considered the oldest text related to Ayurveda. In Atharvaveda we can trace many quotations related to Ayurveda. It also has references of many medicinal plants and their properties and methods of their use in various diseases. As far as the origin and development of Ayurveda is concerned, it is explained on the basis of divine blessings. The king of Gods named Indra has given this knowledge of life to ancient seers for the welfare of mankind (Gorakhnath \& Kashinath, 2008). In Indian philosophical tradition the theory of four goals (Purusharthas) represents the nature of an ideal lifestyle for a human being. This theory prescribes the guidelines and criteria for an ideal human life. Ayurveda considers disease as a major obstacle in the fulfillment of an ideal life. That's why Ayurveda was taught by Indra to some wise Sanyasis (seers) who subsequently taught it to their students. The students then compiled the teachings in the form of texts known as Samhitas. These Samhitas form the original text related to Ayurveda. Some of them are named as Charak Samhita, Sushruta Samhita, Kashyap Samhita and Harita Samhita. Besides these, there are some other very reputed texts related to Ayurveda along with numerous treatise and secondary texts. All these constitute vast literature of Ayurveda.

Ayurveda has 8 parts or branches (Ambikadatta, 2009; Atridev, 2004): 1: Kaya chikitsa (general medicine) 2: Shalya (surgery) 3: Shalakya (ENT) 4: Bhoot vidya (Psychiatry) 5: Kaumar-Bhratya (pediatrics) 6: Aagad tantra (toxicology) 7: Rasayan (methods for sustaining youth and vitality), and 8: Bajikaran (methods for enhancing sexual powers).

Even today Ayurvedic treatment and medicines are very popular among people. Some basic Ayurvedic theories and assumptions are very relevant and meaningful in the present scenario. Presently when human civilization takes the credit of scientific and technical advancements and claims advancements in human progress and quality of life, we also come across the criticisms by scientists regarding rising hazards for human existence. Global warming, constant drastic changes in climate all over the world, unfavorable shifts in weather conditions etc. have put a question mark on all scientific achievements and human progress. It poses a question before all of us whether we are going in the right direction? Have we set a pathway that will lead us to destruction? Ayurveda provides us the guidelines through which we can trace out the structure of an ideal lifestyle for human beings using which we will be able to sustain existence of human race and the beautiful nature around us.

Contrary to what many people believe that Ayurveda is suitable only for particular demographic conditions such as Indian sub continent and particular 
lifestyles such as vegetarianism; its principles are universal and apply to the whole world irrespective of the location or eating habits. Ayurveda prescribes lifestyle for daily routine as well as for seasonal routine which shall be adopted according to the nature of human body and personality.

Ayurveda considers that human being is a part of nature and is not separate from it. If nature or natural environment gets disturbed or imbalanced, then the human body also gets disturbed and distorted. Therefore, it provides guidance not only for the sustenance of the health of a person but also for the survival of human society and protection of the nature simultaneously.

Ayurveda has developed its theoretical structure on the philosophical assumptions. The theories of health and diseases are based on the metaphysical assumptions of Samkhya and Vaisheshika schools of philosophy. In defining disease, Ayurveda considers suffering (Dukh) as a synonym for disease. This is due to the fact that in every case of disease, the element of suffering is invariably present. Therefore, in Indian philosophical tradition the complete removal of sufferings from human life targeted as the principal goal. In Ayurveda also the treatment of disease is the main goal. The difference in their approaches however is that while philosophy deals with the permanent and non recurring concept of suffering removal known as Moksha or liberation; Ayurveda provides medicines and guidance for removing diseases and remaining healthy. According to the philosophical assumptions, Ayuerveda accepts non recurring removal of diseases as a possibility only in the condition of Moksha (liberation) (Gorakhnath \& Kashinath, 2008).

Ayurveda has two main goals i) to maintain the health of a healthy person, and ii) to treat the diseases of an unhealthy person. It provides the guidelines following which a person can remain healthy. The Ayurveda advocates the lifestyle which is ideal not only for maintaining the health of a person but is also ideal for mankind and doesn't harm or distort nature. It is human friendly as well as nature friendly. The values which Ayurveda recommends are those which consider the man not just a biological entity or an organism but as a self conscious, responsible, value bound and rational creature. The message of Ayurveda is for mankind to preserve its nobility and responsibility towards the nature failing which the human race and natural environment both will be at risk of extinction.

Although as compared to modern medical sciences there are hardly any new discoveries and research advancements happening in Ayurveda but from the beginning it has put forward such strong rationales about the nature of human mind and body that it becomes impossible to refute or challenge them even now. Ayurveda is the complete knowledge of life. It has prescribed criteria for appropriate lifestyle, correct regimen and right conduct.

Ayurveda reflects the Indian philosophical thoughts in which the ideal purpose of human life is considered as the liberation from all worldly desires (Moksha). The concept of four Purusharthas (goals) plays a pivotal role in describing the goals and ideal nature of human life.

Ideal human life is considered as the proper balance of these four Purusharthas representing following activities of life: 
1) Sensual Pleasures

2) Economical Gains

3) Laws and Regulations of life

4) Spirituality or thinking about the nature of life

The health of the human body constitutes both physical and mental health. The ideal state of the human body or the nature of the pure mind is a significant factor in human life according to Ayurveda and Indian philosophical traditions. An attempt has been made in this paper to identify the ideal status for human being to attain perfect health. Concepts of health and diseases are discussed in this context and the role of ethical conduct and its impact on desired health is subsequently analyzed.

\section{The Nature of Human Body}

Ayurveda considers human body as shaddhatuj (originating from six elements) (Gorakhnath \& Kashinath, 2008). These are both living and nonliving. The non living or physical elements are known as Panchmahabhutas named Prithivi (Earth), Jala (Water), Tej (Heat), Vyau (Air) and Akash (Space). Not only the human body but the entire physical world is made of these five elements. Every sensory object in this world has the basic constitution of these five elements. These five elements are responsible for the five types of sensations received by sense organs of human body. These sensations are i) smell, ii) taste, iii) vision, iv) touch and v) hearing/sound. When a person dies, it is said the body converts or decomposes to these five elements.

The living or non-physical element is Atma (soul). It is described as 'Knower' (through which one gains knowledge). The soul acts with the help of the body. The relationship between the body and the soul is a complex one. Philosophical thoughts can be used to understand this complex relationship.

In Ayurveda the theories of health and disease have been developed on the metaphysical assumptions of Samkhya and Vaisheshika schools of philosophy. The Samkhya School aims at the removal of all types of sufferings from human life because suffering (dukh) is an integral part of disease. The Vaisheshika School aims at physical attributes of the human body i.e. the Panchmahabhutas named Prithivi (Earth), Jala (Water), Tej (Heat), Vyau (Air) and Akash (Space).

The physical and mental nature of any human being is explained on the basis of these two entities i) the Panchmahabhutas i.e. five elements Prithivi (Earth), Jala (Water), Tej (Heat), Vyau (Air) and Akash (Space) representing physical nature ii) Atma (soul), representing the non-physical element.

These two entities Panchmahabhutas and Atma are eternal. They are neither created nor destroyed. They have always been there. The law of conservation of substance is followed in their case. The human body is made up of these entities. When the body gets destroyed, it converts to these five 
elements. The soul is living and immortal and does not get destroyed. Life is the combination of living and non living. When this combination occurs, the non living substance exhibits goal directed activities. This combination exhibits the emergence of the feeling of 'myself' or 'me' and this feeling is the proof of existence of soul. Although the basic constituents are same for all human beings still each person has a unique combination of these elements giving rise to his or her unique physical nature. Various combinations of these five elements and Atma, results in infinite number of personalities.

The role of the physical constitution of a person is very important in maintaining health as well as in the treatment of diseases. So the knowledge of physical nature is indispensable both for the individual as well as for the doctor. The dietary habits, daily routine, exercises and other physical activities should be carried out in accordance with one's physical nature.

\section{The Nature of the Human Mind}

The way physical nature has multiple combinations; there are infinite number of mental constitutions giving rise to a variety of mental frameworks. In Ayurvedic texts a broad classification of various mental frameworks has been given. In Ayurveda mental framework denotes various personalities. Due to varying personalities, we come across people of different nature such as courageous, religious, corrupt, depressed, strong willed etc. In fact, there are infinite numbers of personalities behaving in infinite ways.

Ayurveda provides justification of these different personalities on the basis of samkhya philosophy. Samkhya philosophy has identified three attributes namely 1)Sattva (knowledge/wisdom), 2)Raja (motion), and 3) Tama (inaction/passiveness) (Ambikadatta, 2009) responsible for this difference in personalities. These three attributes or tendencies are responsible for various human temperaments. A wise person is the one who understands his physical as well as mental nature. A wise man has good control over his body, the way a skilled driver has good control over his vehicle. According to the samkhian system of Indian philosophy, these three tendencies are responsible for the Knowledge, Action and Inaction. The sattva is related to knowledge, raja is related to motion and tama is related to inaction. All the worldly phenomena are nothing but a manifestation of motion and rest of substances or atoms. The three tendencies named under these three attributes give rise to two main types of human personalities - rule abiding and rule violating. The rule abiding personalities are concerned about right and wrong; they bother about their duty, their responsibilities, what they ought to do and what they ought not do. They are concerned about right behavior, about the ideal lifestyle for a human and all the right things. On the other hand, there are people who never get bothered about right or wrong.

Sometimes, it is not easy to decide what is right and what is wrong. In Charak Samhita, a large section is devoted to the rules or the code of conduct for an ideal human life (Gorakhnath \& Kashinath, 2008). Although no set of 
rules can be insufficient to cover all aspects and versatilities of human life, a logical approach and ideology representing relationship between health and ethical conduct is prescribed. In Ayurveda, the ideal lifestyle for a human being is governed by two types of rules namely Swasthavrata (rules for physical health) and Sadvrata (rules for mental health).

Since both mind and body are subject to diseases, one should remain healthy both physically as well as mentally. In the process of attaining this physical and mental health man automatically attains the lifestyle which benefits environment as well as the society. Thus, a healthy body, a healthy society and a healthy environment are interrelated. How this interrelation works, requires an insight into the concept of health and disease.

\section{The Concept of Health}

In Ayurveda, the concept of health is defined as equilibrium between three Doshas namely Air (Vata), Water (Cough) and Temperature (Pitta).. These three Doshas are nothing but the three Mahabhutas: Vyau, Agni and Jala. The air which is present in the body is known as Vata. The heat which is present in the body is known as Pitta. The cough is the moisture (water content) present in the body. Health is the proper balance among these three. These three are also present in the external environment around us. Actually these three are the basic components of the nature. Climate and weather conditions are determined by these three. In the same way, the nature of body depends on the air, temperature and water content present in the body.

Any sort of disturbance in the equilibrium of air, temperature and water (vata, pitta, cough) causes illness. Ayurveda says there may be an infinite number of diseases but they all have the same cause i.e. the imbalance of air, temperature and water in the body. Ayurveda has given much importance to these three while explaining the nature of the human body. They are the three main governing factors of the nature and are addressed as Gods controlling the entire universe and also controlling the body in the form of vata, pitta and cough.

Since these three are physical elements, the physical attributes of body are dependent upon them.

In explaining mental nature, the Ayurveda relies upon samkhya terminology. Ayurveda considers that man is not just a social being but is a rational, responsible, family oriented creature that is born for some purpose. The aim of human life should be noble. It should not be directed towards only getting worldly pleasures. Although worldly pleasures also play an important role in human life but to maximize them is not worthy. They should be enjoyed within limits. These limits are termed as Dharma (religion). Worldly desires and pleasures represent the kama which is one of the purushartha. In Indian philosophy, the aims and quality of human life is explained using the theory of Purusharthas. Human life is purposeful and it should be governed by some rules and regulations while fulfilling its needs. To govern and regulate human 
life, the Purushartha theory has been put forward by Indian philosophers. They have tried to recommend a balanced life which is ideal for human society as well as for an individual. According to this theory Dharma (rules and regulations), Artha (material assistance for pursuing desires), Kama (fulfillment of worldly desires) and Moksha (complete detachment from worldly pleasures) are the four basic goals towards which all human efforts are directed. But these goals should be achieved in such a way that one should not become an obstacle in achieving the other. The Ayurveda came into existence due to this demand of humans that the disease is a major obstacle in the proper fulfillment of Purusharthas. The ultimate goal of human life is considered as Moksha and it can be attained through performing Kama and Artha controlled by Dharma.

As far as the mental nature of a person is concerned, we can briefly say that Sattva represents the most Dharmic (following rules and regulations) personality followed by Rajasic personality and Tamasik i.e. the Tamasik personality will be least rules and regulation following. In Ayurveda, Raja and Tama are considered inferior to Sattva. The way Vata ,Pitta and cough are related to our body, Raja and Tama are considered as causes responsible for malfunctioning of mental capacities. These two doshas are the main cause for misdirecting a person in life. They are responsible for the feelings which enhance the desires, passions, pleasure seeking tendencies in human beings. Once a person becomes a slave to the senses, he becomes Vivek shunya (incapable of judging what is healthy and unhealthy or right and wrong) and falls prey to the reasons causing illness.

\section{The Concept of Disease}

As described above, Ayurveda defines disease as the imbalance of Air, Water and Temperature in the body. When they are in equilibrium the situation is termed as health but when this equilibrium gets disturbed the illness occurs. Three situations of air, water and temperature imbalance are covered in Ayurveda and are referred as Moderate, Excess and Deficient.

'Moderate' represents the healthy state of body while 'Excess' and 'Deficient' represent the state of disease. Ayurveda has identified three causes of diseases 1: Asatmyaindriyarth samyog (wrong interaction of senses with their objects) 2: Pragyanparadh (lack of wisdom) and 3: Parinam (time factor) (Gorakhnath and Kashinath, 2008).

1: Asatmyaindriyarth Samyog (wrong interaction of senses with objects):

It is further classified into three types:

a) Primary senses i.e. those originating from ear, nose, eyes, skin and taste buds.

b) Secondary senses i.e. hands, legs, excretory, reproductive organs and tongue

c) 'Mana' which is also considered as a sense organ (Indriya). 
There are two ways in which the senses comes in contact with their objects i) normal, ii) abnormal. The 'normal' results in health. 'Abnormal' which is further divided in three types (Aati, heen and mithya) is the cause of illness or disease.

\section{2: Pragyanparadh (lack of wisdom)}

An ignorant or careless person can not sustain or remain healthy because he can not avoid the factors causing diseases. Ayurveda says that the body of a wise person remains under his control because he knows what is healthy and what is unhealthy and behaves accordingly.

3: Parinam (time factor).

It caters to diseases caused by changes in seasons, weather etc.

It is advisable that everyone shall follow a lifestyle which helps to avoid all the causes of generation of diseases. In Ayurvedic terminology this type of behavior is known as Sadacharan or Ethical conduct.

\section{The Nature of Ethical Conduct in Ayurveda}

The recommended lifestyle or the Sadacharan can be divided in two parts: i) Swasthavrat and ii) Sadvrata (Ambikadatta, 2009).

Swasthavrat is for physical health and Sadvrata is for mental health and both are inseparably connected.

Swasthavrata is further divided into (Ambikadatta, 2009):

a) ritucharya (rules of regimen according to seasons) and

b) dincharya (daily routine of diet and related activities).

The physical atmosphere of our body changes according to the seasons. The physical constitution of human body is governed by the three factors - air (vata), water (cough) and temperature (pitta). These three constantly change according to the environment around us and therefore our body undergoes changes. Any considerable change in the environment results in change in the human body also. For example in rainy season the moisture or the water content increases in the environment and therefore it increases in our body also. In this season, the water requirements of our body decreases. Keeping this in mind we have to follow the diet plan which helps in maintaining the proper balance or the equilibrium of the three doshas. In Ayurveda this is named as Ritucharya (behavior according to seasons). Dincharya is similar to Ritucharya but focuses on daily routine e.g. during day time and night time. The main objective is to maintain the equilibrium of three doshas (air, water and temperature depending upon the changing situation of the three factors during day and night time. We have to plan our diet and other activities accordingly. It depends totally upon the person how he manages to act and maintains his or her health. 
Besides following Ritucharya and Dincharya, a person should also be well aware of his physical nature (Sharirik Prakriti). Since the three factors (vata, pitta and cough) in human body vary from person to person, something beneficial for one person may not be beneficial to others. Both the vaidya (physician) and the person himself are responsible for knowing the physical and mental nature of a person to cure a disease. Every diet and treatment should be prescribed according to the physical constitution of the person. Similarly mental nature should also be considered. Every act which is related to the health of a person should be performed considering physical and mental nature of that person.

Swasthavrata gives the message that human body should be given importance. Ayurveda assumes that all worldly pleasures can be attained only through a healthy body and therefore we must take proper care of the body to enjoy life.

Sadvrata provides guidance in keeping the mind healthy. In Ayurveda, Raja and Tama are considered as unhealthy mental conditions whereas Sattvic mind is considered healthy. Under the dominance of Rajasic and Tamasic tendencies a person doesn't behave in right manner, he performs actions which are adverse to his health. Sadvrata is the whole set of regimen which a person should follow if he wants his wisdom to guide him in the right kind of direction and to remain healthy. To maintain health a person has to follow a restricted diet, specific life style and proper mindset. Since the body and mind are related with each other, only a correct mental framework will help in achieving the goals of Ayurveda.

\section{Relation between Health and Ethical Conduct}

To understand relationship between health and ethical conduct, we have to recollect the definition of health and disease as per Ayurveda. We know that health is a sort of equilibrium and we can say that the any effort or behavior or lifestyle which is capable of maintaining it will be treated as an ethical conduct. All food that is consumed by us also has the same basic physical constitution like our body i.e. air, water, space, earth and heat, (panchmahabhutas). When this material goes inside our body it gets transformed into body tissues. If any human action destroys the natural properties of these five basic elements, it will affect the human body adversely and will make it ill. These days we notice various herbs, fruits, vegetables have lost their taste and fragrance. Coriander, Rice, Pulses and many others have lost their characteristic flavors and have become tasteless. With such changed characteristics, such material will not act in the human body in the desired or known pattern. It will be devoid of the qualities for which it is known. Charak Samhita (Gorakhnath \& Kashinath, 2008) clearly mentions that as the human beings will become more unethical, the basic nature of physical elements will get distorted and it will adversely affect the human body making it ill. The unethical behavior is the root cause of the unhealthy environment around us. If human acts are performed with greed 
and lusts, they will distract human race from Dharma (rules and laws) of nature. With increase in human desires, such tendencies will further increase resulting in disturbances in the body.

The devaluation starts from our mind and then through human activities it goes into the outer world destroying the basic physical constitution of the substances and ultimately harms our health.

We can trace this chain as manas vikar > rasa vikar > dhatu vikar > sharirika vikar (unhealthy mind $>$ diseased plants > diseased body tissues $>$ unhealthy body). Mental health, physical health and environmental balance all are interrelated. Dharma is nothing but the lawful behavior of human beings which guarantees the protection of health as well as environment.

According to Ayurveda, human life (Ayu) is divided into four types 1) hita ayu 2) ahita ayu 3) sukh ayu 4) dukh ayu. These four types of lifestyles indicate that worldly pleasures are not always good. If they give pleasure in present time but produce harm later, they should be avoided. Human beings while performing any action must always think if this act is right and in accordance with nature because we are all part of nature. Anything which is harmful for the natural environment is harmful for us. The conduct which is not harmful for basic constituents of nature is considered ethical conduct. The knowledge of natural environment, natural laws, aims of human life, ideal nature of human life, the role of a person in family and society; all these can guide a person to act wisely. Such type of action will protect health and nature both.

In Ayurvedic samhitas the disease is also termed as dukha. The complete removal of dukha from human life is the goal of Indian philosophical systems. Ayurveda also says that diseases strike again and again and we can not get rid of them completely forever. Permanent removal of all sufferings including diseases is possible only in moksha. In this situation the mind (mana) becomes pure (sattvic) and the human actions truly ideal.

\section{Conclusions}

Concepts of Ayurveda and Indian philosophy are interwoven. Using these principles it is possible to avoid diseases to the best possible extent.

Ayurveda prescribes ideal life style for human being which is best possible in the natural world. Its principles are strongly built on Indian philosophical concepts. However, these methods are not just suited to Indian environment but apply to all places and all types of foods and ecologies. One needs to determine the ethical conduct and its factors e.g. Dincharya (daily routine) and Ritucharya (season routine) and the tendencies (Rajasic, Tamasic and Sattvic) of actions and inactions. Once these are known, using the right ethical conduct, perfect health free from diseases can be attained.

The relationship is depicted in Figure 1. 
Figure 1. Relationship among Human Tendencies and Diseases

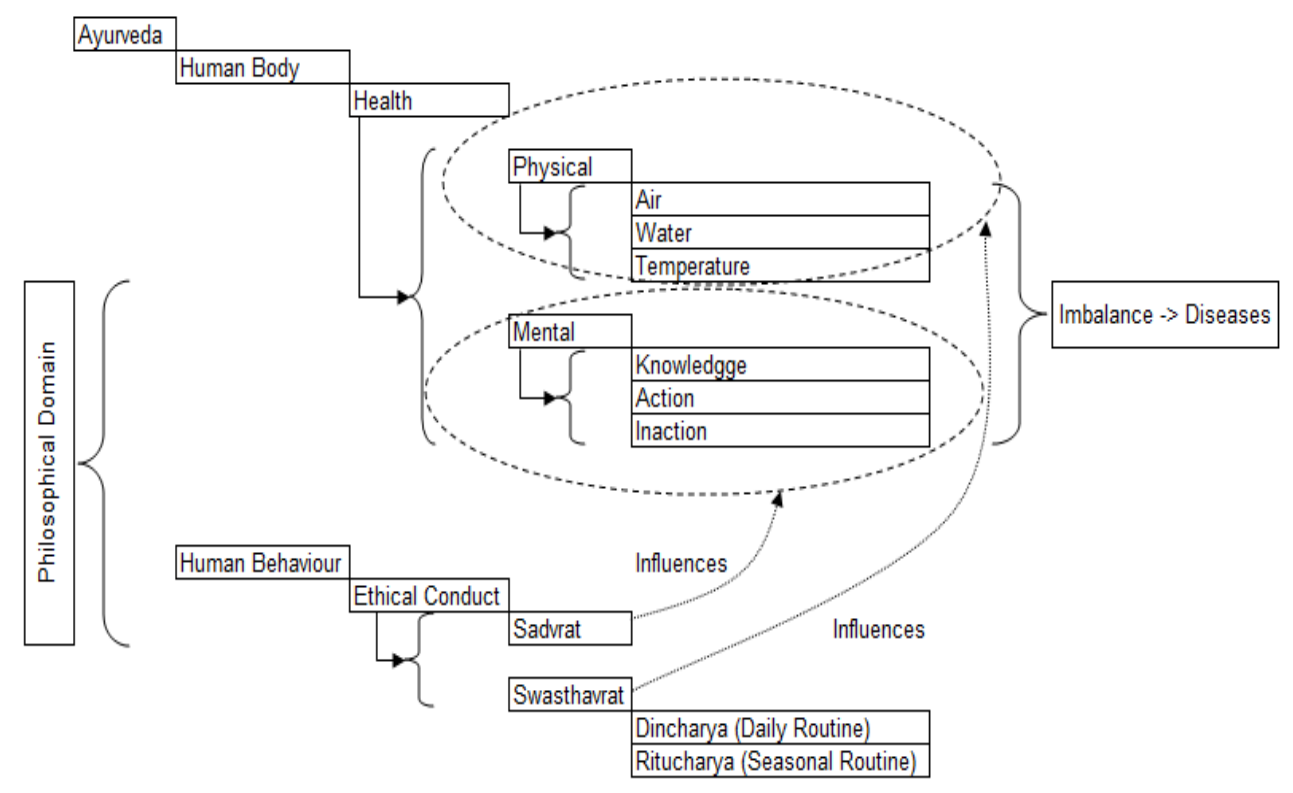

For all human sufferings, the man himself is responsible. Ayurveda puts forward a lifestyle which guarantees a purposeful and pleasurable life.

\section{References}

Ambikadatta Sh. (Commentator), 2009 Reprint, Sushruta Samhita Ayurveda Tatva Sandeepika Hindi Vyakhya, Chokhamba Sanskrit Samsthan, Varanasi.

Atridev G. (Commentator), 2004, Ashtanga Hridayam, Vidyotini Bhasha Tika, Chokhamba Sanskrit Samsthan, Varanasi.

Gorakhnath Ch. and Kashinath Sh. Pt. (Commentators), 2008 Reprint, Charak Samhita, Vidyotini Hindi Translation, Chokhamba Bharati Academy, Varanasi. 
